\title{
SECONDARY SCHOOL MENTOR TRAINING IN SLOVAKIA
}

\section{Beáta Hockicková1, Ružena Žilová ${ }^{\varpi \varpi}$}

${ }^{1}$ Department of German Studies, Faculty of Arts, Constantine The Philosopher University in Nitra, Slovakia, bhockickova@ukf.sk

${ }^{2 \bowtie}$ Department of German Studies, Faculty of Arts, Constantine The Philosopher University in Nitra, Slovakia, Štefánikova 64, Nitra, 949 74, +421904570 414, rzilova@ukf.sk

Highlights

- $\quad$ The manuscript reveals most common weaknesses of novice teachers

- The manuscript reveals the most essential characteristics of "good teaching"

\begin{abstract}
The aim of the research study was to present qualitative data from a mentor training pilot designed as continuous professional training of teachers for the position of mentor. Accordingly, essential key competences referred to as representing teachers' further professional development were identified in the current research study. Based on the results collected from the pilot seminars carried out through the course of the research as well as results collected from completed questionnaires for mentors, actual and potential problems and the needs of secondary school teachers in Slovakia were identified. The presented research results are a summary of the collected research data.
\end{abstract}

\section{Keywords}

Key competences, lifelong education, mentor, novice teacher
Article type

Full research paper

Article history

Received: March 4, 2015

Received in revised form: October 24, 2015

Accepted: October 26, 2015

Available on-line: November 24, 2015

\begin{abstract}
Hockicková B., Žilová R. (2015) "Secondary School Mentor Training in Slovakia", Journal on Efficiency and Responsibility in Education and Science, Vol. 8, No. 3, pp. 60-66, online ISSN 1803-1617, printed ISSN 2336-2375, doi: 10.7160/ eriesj.2015.080302.
\end{abstract}

\section{Introduction}

Teachers' competences and ways in which to improve teachers' practice has been the focus of a variety of initiatives across Europe. Much of this has concentrated on the production of explicit indicators for teacher quality (Strong, 2011; Zumwalt and Craig, 2005), in terms of competence, standards (Fisher, 2005; Koster and Dengerink, 2008). The importance of careerlong updating and development for practicing teachers has been recognized (Danielson, 2007; Key, 2010) and practicing teachers have become increasingly involved in the training of new entrants (Malá, Müglová and Hockicková, 2013) to the profession in many countries. To support this movement the European Commission has developed the Common European Principles for Teacher Competences and Qualifications (Common, 2005). But there is no common focus on the specific needs of those who will induct and support novices in schools, i.e. mentors. In several EU countries (as e.g. in the Netherlands, Portugal, Austria and Germany) mentors have become a valued and integral part of the pre-service training of teachers (Skaniakos, Penttinen and Lairio, 2014); in a few countries (e.g. in Ireland and Belgium), they are also involved in the induction and support of new entrants to the profession. However, as also Hopkins and Spillan (2014) state there are not many studies which focus specifically on mentors ("schoolhouse teacher educators"). In their study they focused mainly on such questions as who is doing the work of novice teacher education at schools and how these educators support novices, but there is nothing about support given to mentors. Similarly the study of De Angelis, Wall and Che (2013) examines the direct effects of preservice preparation quality and early career support on career intentions and decisions of novice teachers, but again it gives no data on mentors' support.
Novice teachers' professional induction in the Slovak Republic is legislatively guaranteed by Decree No. 445/2009 on the further education of teaching staff in $\S 4$ and Act No. 317/2009 on teaching staff and professional employees officially introduces the role of mentor-teacher. The Act partially defines specific activities and responsibilities of mentors, but it says nothing about the necessary preparation or training for this position. The first attestation and several years of teaching experience are considered to be adequate preparation for this position (Zákon No. 317/2009, § 33, par. 3). Besides the official legislative standing, there is also a network of Methodology and Educational Centres (so-called MPC: Metodicko-pedagogické centrum) in all regional cities in Slovakia. These centres play quite an important role in raising teachers' awareness in many areas of education, including mentoring (Výbohová, 2012: 9-10). They organize various in-service courses and events for teachers and also publish supporting educational materials.

The main purpose of the research project Key Competencies of Mentors Necessary for Efficient Mentoring of Newly Qualified Teachers (supported by National Research Agency VEGA under the number $1 / 0677 / 12$ ), carried out by a team of professional education instructors from the Faculty of Arts at the University of Constantine the Philosopher in the city of Nitra, Slovakia was to identify key competences necessary for highly professional mentoring of novice teachers at secondary schools in Slovakia. Furthermore, the project was aimed at designing practical tools for the structuring and developing of key competences by specifically designed theoretical and practical study materials. The project team of professionals built on the presumption that very little and non-systematic attention had been paid to the graduates of teaching programmes at faculties of education 
in Slovakia (at such universities as Comenius University in Bratislava, Constantine the Philosopher University in Nitra, Presov University in Presov, Matej Bell University in Banska Bystrica et al.). Teachers have had no or very little practical or theoretical professional training or any kind of professional support in order to become educated and trained in the field of novice-teacher mentoring, nor have they had any or very little specific skills, abilities or competences developed and trained to be able to manage the role of novice-teacher mentor.

In order to improve education at secondary schools in Slovakia the project team of professionals directed their attention towards the research and analysis of both positions: mentor, as well as novice teacher. Apparently, the aim was to design a structural framework of mentors' key competences essential for the successful mentoring of novice teachers. Moreover, the results of the research study - theoretical and practical materials were officially published in a book Formovanie kompetencii uvádzajúceho učitel'a (Gadušová et al, 2014).

The aim of the paper is to present qualitative data from a mentor training pilot in which usefulness and quality of a selected number of tasks published in the book (Gadušová et al, 2014) were tested. The paper presents the ways in which the seminars were run and describes the reactions of the participants to the tasks, presents their opinions and suggestions regarding mentor training.

\section{Materials and Methods}

For piloting the materials designed for publishing in the book (Gadušová, 2014) five training workshops for mentors were organized in schools of western Slovakia in spring 2014. Out of about 100 tasks designed for the book due to limited time for allocated for workshops (90-120 minutes) from each chapter of the book only 2-3 tasks were selected in order to test the tasks from each area addressed in the book. The workshops were organized on voluntary basis so as to attract only those teachers who really are interested in the issue. Furthermore, the researchers wanted to have manageable groups of trainees (about 12-15 in each group) in order to have the workshops very interactive. The different training tasks selected for the workshops were presented one by one, first the workshop participants were given some thinking time to read the task, recall their experiences and prepare some comments which then were discussed in groups and subsequently with trainers.

Regarding terminology, key competences were defined variably depending on sources (Kramárová, 2010, Kasáčová and Kosová, 2006, Bagalová, 2005, Baumert, Kunter and Blum, 2011, Veteška and Tureckiová, 2008), therefore, in the research study the features of key competences were referred to as follows: dynamic, complex, active and procedural competences, which are measurable and certifiable.

Mostly, competences are related to knowledge, abilities and skills. Veteška and Tureckiová (2008: 31), for example, see the relationship between abilities and competences in the process of education as follows:
ABILITY

\section{COMPETENCE}

Input $\rightarrow$ Output

potential for action effectively managed action

Teachers in contemporary society are assigned many roles, tasks and positions they need to manage throughout their teaching careers (Nálepová, 2013: 18). As for the key elements there are several essential competences covered in the following statements. Bauer (2002: 50) mentions that nowadays, several competences are considered to be key competences in education: targeted planning, time and class management, use of teaching methods and approaches, and the carrying out reflection on the learning and teaching process. Teaching is based on specific competences, such as subject competence, and scientific, didactic and psychological competences. However, non-cognitive or meta-cognitive competence is essential, too. It is referred to as the ability to co-operate, readiness to learn, and the ability to maintain one's own mental and physical health.

Referring to the abovementioned concepts, key competences in the presented research study are considered to be those which are stated in the National Educational Programme for ISCED 1-3 (Štátny vzdelávací program, 2008 - 2009). Out of the great variety of definitions of teachers' competences we tried to select those which will create a basis for mentor teacher competences.

We agree with Baumert, Kunter and Blum (2011: 31) who include among professional teachers' competences the following: Beliefs, Motivation, Self-regulation and Professional Knowledge. To these areas of competences they match the relevant skills in the way as it is listed in the Table 1.

\begin{tabular}{|l|l|}
\hline Competence Areas & Competence Related Skills \\
\hline Subject competences & Deep understanding of the subject taught \\
\hline $\begin{array}{l}\text { Special didactic com- } \\
\text { petences }\end{array}$ & $\begin{array}{l}\text { Ability to present and explain the subject } \\
\text { Awareness of learners' thinking processes } \\
\text { Awareness of assignments and tasks }\end{array}$ \\
\hline $\begin{array}{l}\text { Psychological } \\
\text { competences }\end{array}$ & $\begin{array}{l}\text { Knowledge about testing and evaluation } \\
\text { Knowledge about learning and teaching } \\
\text { processes } \\
\text { Knowledge about effective class } \\
\text { management }\end{array}$ \\
\hline $\begin{array}{l}\text { Organizational compe- } \\
\text { tences }\end{array}$ & $\begin{array}{l}\text { Abilities to plan, co-ordinate, control, } \\
\text { elicit activities, set limits, make decisions, } \\
\text { and meaningfully assign tasks }\end{array}$ \\
\hline $\begin{array}{l}\text { Interpersonal (social) } \\
\text { competences }\end{array}$ & $\begin{array}{l}\text { Abilities to manage relationships with } \\
\text { students, colleagues } \\
\text { Abilities to communicate } \\
\text { Abilities to care for others, be tolerant } \\
\text { and flexible }\end{array}$ \\
\hline
\end{tabular}

Table 1: List of competences and skills

Referring to the abovementioned key competences the project team members selected the competences directly related to the research issues. These were the area of competences related to pedagogical and psychological knowledge and its inseparable parts, mainly: knowledge about teaching and learning processes. This competence is described in more detail in a published book (Gadušová et al, 2014) which is an output of the VEGA project results. 
Based on the identification of the key competences specifically defined for the position of mentors and novice teachers after entering the teaching profession at school, the project team members designed a set of procedures for the formation and development of the identified mentor competences. Moreover, a set of practical and theoretical educational materials was designed on the basis of both real school examples as well as newly created ones. The educational materials were piloted and evaluated as a part of mentor-training seminars for about 60 secondary school teachers from various regions of Slovakia through the months of February and March 2014.

Among the key seminar topics were: communicative and interpersonal skills, mentoring skills, monitoring and observation skills, management skills, and skills of evaluation and self-reflection. The aim of the seminars was not only to introduce the philosophy behind the designed training materials for teachers but also to review, critically assess and get feedback about selected tasks and assignments from the planned academic publication.

\section{Results and Discussion}

Out of the designed materials (which have been published in the meantime) we selected several tasks to be piloted in the seminars and we present them below. The seminar participants answered the presented questions and they answers are summarized in the Table 2. The questions related to expectations of mentors while observing novice teachers as far as novices' efficiency of performance during lessons, then, they also expressed to what extent their expectations matched the situation and in which areas of novices' performance. We present examples collected from seminar participants. Their statements have been generalized and they addressed the following aspects of teaching.

Next, the samples of tasks follow. We present examples completed by seminar participants.

What did you expect when observing a novice teacher? Were your expectations met? If your response is YES, please, describe how. If your response is NO, please describe why.

\begin{tabular}{|l|l|l|}
\hline $\begin{array}{l}\text { Mentors } \\
\text { expectations from } \\
\text { novice teachers }\end{array}$ & $\begin{array}{l}\text { Met } \\
\text { expectations } \\
\text { (state examples) }\end{array}$ & $\begin{array}{l}\text { Not met expectations } \\
\text { (state examples) }\end{array}$ \\
\hline $\begin{array}{l}\text { To get a new } \\
\text { perspective of a } \\
\text { lesson. }\end{array}$ & $\begin{array}{l}\text { Approximately } \\
\text { to } 10 \% .\end{array}$ & $\begin{array}{l}\text { My expectations were } \\
90 \% \text { not met because } \\
\text { students were scared; } \\
\text { they were not creative } \\
\text { enough; some teachers } \\
\text { overestimate their } \\
\text { abilities; some teachers } \\
\text { were not prepared for } \\
\text { lessons. }\end{array}$ \\
\hline $\begin{array}{l}\text { Students will use } \\
\text { mew teaching } \\
\text { methods they learnt } \\
\text { at university, will } \\
\text { be enthusiastic and } \\
\text { creative. }\end{array}$ & $\begin{array}{l}\text { Students used } \\
\text { new materials } \\
\text { and new forms } \\
\text { of teaching and } \\
\text { were creative. }\end{array}$ & $\begin{array}{l}\text { Some of their } \\
\text { assignments were too } \\
\text { easy and not appropriate } \\
\text { for the learners' level of } \\
\text { language proficiency; } \\
\text { they were not aware } \\
\text { of the extent of the } \\
\text { language the learners } \\
\text { have already acquired } \\
\text { and, therefore, they were } \\
\text { not able to describe } \\
\text { assignments properly. }\end{array}$ \\
\hline
\end{tabular}

\begin{tabular}{|c|c|c|}
\hline $\begin{array}{l}\text { Students will } \\
\text { be able to find } \\
\text { additional teaching } \\
\text { materials on the } \\
\text { internet as they are } \\
\text { highly computer } \\
\text { literate. }\end{array}$ & $\begin{array}{l}\text { It was not always } \\
\text { so (i.e. mentor's } \\
\text { expectations } \\
\text { were not always } \\
\text { met). }\end{array}$ & $\begin{array}{l}\text { The novice teacher I was } \\
\text { observing was not well } \\
\text { prepared for the lesson. } \\
\text { Young teachers often } \\
\text { thought it is enough to } \\
\text { appear in front of the } \\
\text { class and speak without } \\
\text { any planning ahead. } \\
\text { Some of them were not } \\
\text { confident enough; their } \\
\text { language proficiency } \\
\text { was not at an advanced } \\
\text { level. }\end{array}$ \\
\hline $\begin{array}{l}\text { I expected well- } \\
\text { executed lesson } \\
\text { planning and fluent } \\
\text { use of language. }\end{array}$ & $\begin{array}{l}\text { Lesson plans } \\
\text { were not always } \\
\text { executed as it } \\
\text { was planned due } \\
\text { to lack of time. }\end{array}$ & $\begin{array}{l}\text { They were not } \\
\text { independent in lesson } \\
\text { planning. Lesson } \\
\text { planning had to be } \\
\text { consulted with them. } \\
\text { They could not } \\
\text { differentiate between } \\
\text { bilingual and non- } \\
\text { bilingual classes. }\end{array}$ \\
\hline $\begin{array}{l}\text { I expected that } \\
\text { a novice teacher } \\
\text { would be able to } \\
\text { begin, conduct and } \\
\text { finalize the lesson; } \\
\text { that they would be } \\
\text { able to explain the } \\
\text { language without } \\
\text { any mistakes; they } \\
\text { would be on good } \\
\text { terms with young } \\
\text { learners. }\end{array}$ & $\begin{array}{l}\text { Met only } \\
\text { partially (up to } \\
40 \% \text { ). }\end{array}$ & $\begin{array}{l}\text { They did not correct } \\
\text { learners' errors and } \\
\text { mistakes; they expected } \\
\text { mentors to do it. }\end{array}$ \\
\hline $\begin{array}{l}\text { I expected that a } \\
\text { novice teacher, } \\
\text { who was just } \\
\text { starting his/her } \\
\text { career, would } \\
\text { become aware of } \\
\text { lesson content and } \\
\text { its structure, as } \\
\text { well as teaching } \\
\text { forms. }\end{array}$ & $\begin{array}{l}\text { Met to } 90 \% \text {, i.e. } \\
\text { in majority of } \\
\text { cases. }\end{array}$ & $\begin{array}{l}\text { As they were just } \\
\text { novice teachers they } \\
\text { could not follow all } \\
\text { the interactions in the } \\
\text { lesson. }\end{array}$ \\
\hline $\begin{array}{l}\text { I expected that } \\
\text { they would fill in } \\
\text { the appropriate } \\
\text { observation sheet } \\
\text { during their lesson } \\
\text { observation. }\end{array}$ & $\begin{array}{l}\text { I could see that } \\
\text { they filled the } \\
\text { observation } \\
\text { sheet. }\end{array}$ & $\begin{array}{l}\text { They did not fill in the } \\
\text { appropriate observation } \\
\text { sheet as they didn't } \\
\text { consult which one to } \\
\text { fill in. }\end{array}$ \\
\hline $\begin{array}{l}\text { I expected that } \\
\text { a novice teacher } \\
\text { would consult his/ } \\
\text { her lesson plan } \\
\text { with his/her mentor } \\
\text { before the lesson } \\
\text { begins. }\end{array}$ & $\begin{array}{l}\text { Not every } \\
\text { student did it. }\end{array}$ & $\begin{array}{l}\text { Some of the novice } \\
\text { teachers did not do that. } \\
\text { The teaching material } \\
\text { was not linked to the } \\
\text { previous lesson. }\end{array}$ \\
\hline $\begin{array}{l}\text { I expected that the } \\
\text { lesson plan would } \\
\text { be prepared co- } \\
\text { operatively. }\end{array}$ & $\begin{array}{l}\text { Most of the } \\
\text { lessons were } \\
\text { well-taught. }\end{array}$ & $\begin{array}{l}\text { The mentor didn't } \\
\text { have time to reflect } \\
\text { on the lesson with the } \\
\text { novice teacher. The } \\
\text { mentor did not point } \\
\text { out the strengths and } \\
\text { weaknesses of the } \\
\text { lesson. }\end{array}$ \\
\hline
\end{tabular}

Table 2: Mentor's expectations from a novice teacher's observation 
The seminar participants suggested that the cooperation with novice teachers should be based from the beginning on mutual understanding of the purpose of lesson observations. They should improve quality of novices' teaching, never humiliating or discouraging novice teachers.

One of the important aims of the pilot seminars was also to find the most serious drawbacks of novices that mentors can observe during the novices' first year at school. In the task there were listed 20 most frequent drawbacks of novices. The table was filled in by 60 of workshop participants, but they expressed their opinions only about 13 drawbacks. Their responses are presented in the Table 3 in the order of frequency of their answers about different drawbacks.

Based on your observations, which of the following issues do you consider to be novices' most common weaknesses? Use tick to mark your response.

\begin{tabular}{|l|l|c|}
\hline & Most common weaknesses of novice teachers & Limitations \\
\hline 1. & Lack of subject knowledge. & $16.65 \%$ \\
\hline 2. & Lack of novice teacher charisma. & $33.20 \%$ \\
\hline 3. & Irresponsible attitude to teaching. & $33.20 \%$ \\
\hline 4. & $\begin{array}{l}\text { Inappropriate use of teacher's voice during } \\
\text { lessons. }\end{array}$ & $50.00 \%$ \\
\hline 5. & Problems with learners' motivation. & $66.6 \%$ \\
\hline 6. & Insufficient use of teaching aids. & $83.2 \%$ \\
\hline 7. & Insufficient lesson planning. & $16.65 \%$ \\
\hline 8. & Lesson plan not executed in real teaching. & $100 \%$ \\
\hline 9. & Anxiety of learners. & $33.20 \%$ \\
\hline 10. & Fear of being observed. & $16.65 \%$ \\
\hline 11. & Lesson timing not executed successfully. & $100 \%$ \\
\hline 12. & Grading of learners not objective. & $16.65 \%$ \\
\hline 13. & $\begin{array}{l}\text { Lack of coherent flow of lesson procedures and } \\
\text { activities. }\end{array}$ & $33.20 \%$ \\
\hline
\end{tabular}

Table 3: Weaknesses of novice teachers

Based on the feedback collected from informal discussions with the seminar participants, as seen in the Table 3, the biggest problems novice teachers have to face are the following: ability to follow lesson plans while teaching, lesson time management, and insufficient use of teaching aids. Furthermore, novice teachers experience some problems with motivation of learners in studying the subject. The other benefit of the seminars was that teachers shared their experiences and mutually discussed a variety of their suggestions on how to deal with different problem situations.

The last of the piloted tasks was aimed at finding the most important attributes of ,good teaching“ out of those listed in the Table 4. (Meyer, 2004:17-18).

What do you think "good teaching" should look like? Select five features you consider the most essential.

\begin{tabular}{|l|c|}
\hline Teaching should help learners to: & Limitations \\
\hline learn what they will need in real life & $100 \%$ \\
\hline learn things they are interested in & $24.5 \%$ \\
\hline enjoy learning & $35.2 \%$ \\
\hline $\begin{array}{l}\text { express themselves and discuss what they have } \\
\text { learned }\end{array}$ & $86.4 \%$ \\
\hline work in groups & $18 \%$ \\
\hline express their ideas and thoughts & $66.5 \%$ \\
\hline $\begin{array}{l}\text { work and think independently } \\
\text { take part in decision-making processes regarding } \\
\text { learning content and its extent }\end{array}$ & $59.2 \%$ \\
\hline $\begin{array}{l}\text { learn what they are expected to achieve during week- } \\
\text { days so that they are free on weekends }\end{array}$ & $25.4 \%$ \\
\hline $\begin{array}{l}\text { learn appropriate ways of effective and successful } \\
\text { learning }\end{array}$ & $61.3 \%$ \\
\hline
\end{tabular}

Table 4: Features of good teaching

Based on evaluation of this task we have compiled the list of attributes with their importance for the "good teaching". According to the mentors' opinions collected during the pilot seminars the following 5 attributes are the most beneficial for learners: learning what they need in real life, expressing themselves and discussing what they have learned, expressing their ideas and thoughts and learning appropriate ways of effective and successful learning and learning how to work and think independently. The other attributes were not considered to be of serious importance.

Considering the analysis of data collected from the questionnaires distributed at the end of seminars, we can say that teachers considered the seminars to be beneficial both theoretically and practically. In the following part we present statements of teachers regarding selected tasks and assignments from the project publication mentioned above:

1. The answers in the questionnaires to the question "Which assignments and tasks do you find useful for the work of a mentor?" were as follows (in their answers teachers stated the tasks' focus):

- Management skills.

- Observation, monitoring, expert teaching, evaluation and self-reflection.

- Each task was specific / all tasks were helpful as they enabled the realization and thinking about different aspects of mentors' work / they help develop awareness of the important and challenging aspects of the teaching job / in these tasks there was everything I would definitely use when mentoring a novice teacher.

- I liked the assignment about novices' weaknesses because it is interesting to know other teachers'findings, to confront them and discuss possible ways of dealing with them. This may help mentors' work.

- I found the assignment Features of Good Teaching as a useful one; a mentor could use it as a guiding example for novice teachers.

- I liked the assignments about monitoring and observation; they helped me to realize my own expectations and possibilities for their achievement as well as to reconsider students 'readiness for the teaching profession.

- For mentors I found most beneficial the assignments about monitoring and observation as they provide 
a detailed view of the observation of the teaching process. Furthermore, they make mentors aware in detail of the different aims and types of observation as well as about the essential aspects of observation. Inspection and evaluation of the teaching process through observation is one of the most important elements of internal school assessment. However, it is essential to provide feedback in order to improve quality of teaching.

- The assignment related to management skills, as I think this is the issue where a mentor can pass valuable advice to a novice teacher and tell him/her how to solve problem situations using methods and techniques proven and tested in practical teaching at a school where a novice teacher starts his/her career.

- I liked the task about personal and professional development of mentors by means of reflection and selfreflection.

\section{Summary No.1:}

Teachers were impressed by the presented assignments; they tried to point to their justification and importance for mentor development. These tasks help them realize:

- the significance of novice teachers' mentoring

- the most important features of good teaching

- the partial aims of observations and their expected attainability

- the value of reflection and self-reflection for personal and professional development of mentors.

We can conclude that the project team selected the most vital topics from the area of mentor training and their further professional development.

2. The above mentioned conclusion can be exemplified by statements of seminar participants who were asked to express their opinion on whether they considered this type of training necessary and useful or not. The participants of

the pilot training stated:

- Yes, this may unify the requirements of mentors regarding novice teachers and improve the work of mentors.

- It is essential to have a complex, non-subjective perception of the requirements of novice teachers. Some of the tasks were very useful even for me, though I have been teaching many years.

- It is a set of various requirements and abilities, which are familiar and routine for an experienced teacher but in this way are clearly structured and formulated.

- This kind of training helps mentors to identify and analyse limitations and problems of novice teachers and show ways of dealing with them. It helps mentors to cooperate better with novices and stimulate them to gain practical experience necessary for using their full potential in their school work, and to gain professional competences necessary for their independent performance in the field of teaching.

- The presented method of mentor training is useful because it is complex and it is aimed at the most frequent issues and situations which mentors face. Awareness of them helps mentors who are really interested in mentoring to mentor novices and assist them in becoming professional teachers. I would appreciate the opportunity to participate in such seminars for mentors in the future.

\section{Summary No. 2:}

Teachers expressed strong support for the professional training of mentors. The need for further education in this field is based on their willingness to approach the role of mentor with ample responsibility. For the work of mentor the seminar participants find the most important the following issues:

- $\quad$ theoretical knowledge of mentors

- $\quad$ unifying mentors' requirements regarding novice teachers

- the opportunity to identify and analyse weaknesses of novice teachers in their teaching and ways of overcoming them.

3. The question in which seminar participants were asked about the specific activities and training techniques mentors' training should include was answered as follows:

- Possibility to analyse video-recordings of real lessons, novice teachers'lesson plans and analytical discussions of novice teachers with mentor teachers.

- Suggestions on how to guide novice teachers, how to motivate them to improve their work, as very often novices do not show enthusiasm and willingness to teach.

- Mentors' education and training should be oriented towards real school issues. Part of this training should comprise how to make a novice aware of the work (including administrative work and pedagogical documents) of a class teacher or a head of subject committee teacher.

- It should contain analysis and possible solutions for model situations taken from the real teaching experience of teachers involved in the training. This would show trainee teachers how to transform and apply their theoretical knowledge to the conditions of real teachers.

\section{Summary No. 3:}

Seminar participants have a clear idea about the content of their further professional training. They see their greatest reservations in the:

- lack of theoretical and practical knowledge in the methodology of subject teaching

- lack of specific formulations and tasks of mentors' role

- lack of specific formulations mentors need to analytically observe and evaluate novice teachers and their achievements.

4. The seminar-participants were also asked whether they would like to participate in this kind of training or whether they would recommend it to their colleagues. Their answers were as follows:

- Yes, I would recommend it. It is essential for any teacher to achieve their full potential and to realize what is really important in the teaching profession. Some teachers stagnate, thinking that they do not need any further education. 
- Certainly yes. There is no time to exchange and share experiences among mentors during the school year. The training would be useful for any mentor.

- Any teacher can become a mentor after some years of teaching experience. Apparently, it is vital for teachers to be prepared theoretically and practically for the position of mentor.

- This type of training is useful. Personally, I would be interested in participating in such seminars, if my school management creates suitable conditions for my participation. I would definitely recommend it.

\section{Summary No. 4:}

Almost all seminar participants expressed interest in participation in this kind of training in future and would recommend it to other teachers. As the main reasons they stated the following:

- creating a common platform for sharing mentoring experience and gaining new knowledge about mentoring

- creating conditions for training new mentors with participation of practising mentors

5. Finally, the seminar participants were asked whether the seminar helped them to see differently the role of mentor and how their view of mentors has changed. We present some of their answers:

- After precise reading of the presented assignments I realized how important and responsible the job of mentor is. They must be experts in their job and be able to carry out the role of mentor, and have a responsible approach to the guidance of novices.

- I realized how important it was to have a skilful, smart and empathic mentor.

- Selected phenomena were clearly named and structured, so I will be able to communicate with novice teachers better; I will be more aware of what is important not only for their evaluation but mainly for their systemic guidance.

- I have just started mentoring so I was happy to get theoretical background and summary of the role of mentor.

- This training enabled me to gain a more complex overview of the job of mentor. A mentor should view novice teachers as equal partners. However, they should not avoid constructive criticism from both sides. Neither novice teacher nor mentor should forget to self-reflect and get feedback from their job. They should bear in mind that both sides are responsible for the improvement of education in our schools.

- In my opinion the job of a mentor teacher is much more difficult than the job of a novice teacher. It is a mentor's job to introduce a novice teacher to the world, which at first reminds one of the galleys but later becomes his/ her life. A mentor has to prepare a novice teacher for a demanding journey full of obstacles and bureaucracy. However, on the other hand, it is a journey full of beautiful experiences, friends for life, memories and what's more, it is also an opportunity to work with children.
- Mentoring novice teachers is very often accompanied by a lack of time which should be given to novices. Lack of time, in many cases, makes it impossible to fully commit them to mentoring.

- I gained a new point of view regarding mentoring novice teachers. I had the opportunity to realize various aspects that influence the work of mentors in the period of novices' induction. I also gained many ideas I could utilize in my continued role as a mentor.

\section{Summary No. 5:}

Apparently, teachers received a more complex point of view on mentoring novice teachers. Specifically mentioned areas were as follows:

- seminar participants realized more deeply and in all particularities what the job of mentors comprises

- seminar participants gained a new point of view of the relationships between mentors and novice teachers; they view novice teachers as equal partners who need appropriate guidance in the field of subject teaching, methodology of their work and mainly improvement of their interpersonal competences.

Pilot workshops, in which a sample of 60 teachers from various regions of Slovakia took place, tested a selected number of tasks from the upcoming publication aimed at training of mentor-teachers from primary and secondary schools. The data collected during the workshops and from analyses of interviews with workshop participants clearly confirmed the need for development of training materials for mentors. As stated in the Introduction, the issue of mentors' support is, in general, paid little attention both abroad and in Slovakia. Thus, the published book represents the first, relatively complex, methodological materials for mentor training and their support in Slovakia. The universities and other educational institutions providing continuous professional development of teachers can make much use of the book when training not only prospective mentors, but also school leaders who - as stated in the legislative documents (Zákon No. 317/2009 Z. z., Vyhláška MŠ SR No. 445/2009), are responsible for induction phase of novice teachers. However, the book was designed not only for face to face use and training of teachers (whether the mentors or the school leaders) but it can also be used as the self-study material as it is freely available online at http://www.ff.ukf.sk/index.php/pre-autorov/strukturafakulty-all/15-dalsie/686-prehlad-publikacii-vydanych-ff-ukf (the book opens after clicking on its cover page). As to its content, not only the book but also this paper, thus, increases the small number of publications dealing with the support of mentors both in national and international context.

\section{Conclusion}

Interconnection of theoretical knowledge and practical experience in teacher training is equally important for higher education institutions as for lower and upper secondary schools. It is a pity that this cooperation between both parties has not functioned in such a way that it is beneficial for both of them. That is why a team of university teachers (researchers) at the University of Constantine the Philosopher decided to take part in the research project VEGA 1/0677/12 Key Competencies of Mentors Necessary for Efficient Mentoring of Newly Qualified Teachers and thus contribute to the improvement of the existing situation. The project was aimed at the identification of the key 
competences necessary for the high quality of professional mentoring of novice teachers. Furthermore, the project was aimed at identifying and analysing the needs of mentors and novice teachers. The research team verified the project outputs with lower and upper secondary school teachers in pilot seminars. The seminars were aimed not only at evaluating the designed study materials for mentor training but also at getting critical feedback on selected practical assignments from the developed educational materials.

Analysis of the data collected from the questionnaires distributed after seminars showed positive findings concerning the use of practical assignments as well as the theoretical basis of the academic publication. Mentor teachers expressed interest in this publication and the practical training assignments presented in the book.

\section{Acknowledgements}

The paper is based on research findings within the project VEGA 1/0677/12 Key Competences of Mentors Necessary for Successful Mentoring of Novice Teachers.

This work was also supported by the Slovak Research and

Development Agency under the contract No. APVV-14-0446.

\section{References}

Bagalová, L'. (2005) 'Kl'účové kompetencie - nové možnosti vo výchove a vzdelávaní', Pedagogické spektrum, Vol. 14, No. 5-6, pp. 64-72.

Bauer, K.-O. (2002). Kompetenzprofil: LehrerIn. In H.U.O.T. Rauschenbach \& P. Vogel (Hrsg.), Erziehungswissenschaft: Professionalität und Kompetenz (pp. 49-63). Opladen: Leske\& Budrich.

Baumert, J., Kunter, M. and Blum, W. (2011) Professionelle Kompetenz von Lehrkräften: Ergebnisse des Forschungsprogramms COACTIV, Münster: Waxmann Verlag. Common (2005) Common European Principles for Teacher Competences and Qualifications, European Commission, Directorate-General for Education and Culture, Brussels. [Online], Available: http://europa.eu.int/comm/education/ policies [Mar 2015].

Danielson, Ch. (2007) Enhancing professional practice: A framework for teaching, $2^{\text {nd }}$ edition, Alexandria, Va.: Association for Supervision and Curriculum Development.

DeAngelis, K. J., Wall, A. F., Che, J. (2013) The Impact of Preservice Preparation and Early Career Support on Novice Teachers' Career Intentions and Decisions. Journal of Teacher Education. Vol. 64, No. 4.

Fisher, R. L. (2005) Standards for Teacher Educators: Preparing High Quality Teachers, [Online], Available:

http://www.education.pearsonassessments.com/hai/images/ NES_Publications/2005_14Fisher_549_1.pdf [Mar 2015].

Gadušová, Z. et al. (2014) Formovanie kompetencii uvádzajúceho učitel'a. Nitra: FF UKF.

Hopkins, M. and Spillane, J. P. (2014) Schoolhouse Teacher Educators: Structuring Teachers Opportunities to Learn about Instruction. Journal of Teacher Education. Vol. 64, No. 4.

Kasáčová, B. and Kosová, B. (2006) 'Kompetencie a spôsobilosti učitel'a - európske trendy a slovenský prístup', Profesijný rozvoj učitel'a, Prešov: MPC, pp. 37-49.

Key (2010) Key Competencies for Lifelong Learning A European Reference Framework. Implementation of Education and Training, Work programme. [Online], Available: http://europa.eu.int [Mar 2015].
Koster, B. and Dengerink, J. (2008) 'Professional standards for teacher educators: how to deal with complexity, ownership and function. Experiences from the Netherlands'. European Journal of Teacher Education, Vol. 31, No. 2, pp. 135-149.

Kramárová, M. (2010) Cudzojazyčná edukácia v kontexte rozvoja klúčových kompetencií. Universitatis Tyrnaviensis: Typi.

Malá, E., Müglová, D. and Hockicková, B. (2013) 'Faktory ovplyvňujúce úspech začínajúceho učitel'a', Cudzie jazyky a kultúry v škole 10. Nitra: UKF, pp. 107-115.

Meyer, H. (2004) 'Was ist guter Unterricht?'. Berlin: Cornelsen Verlag Scriptor. [Online], Available: http://www.staff.unioldenburg.de/hilbert.meyer/9290.html [Feb 2015].

Nálepová, J. (2013) 'Učitelé cizich jazykì, jejich profesní životopisy a názory na současné školství’. Opava: Slezská univerzita v Opavě.

Skaniakos, T., Penttinen, L. and Lairio, M. (2014) 'Peer Group Mentoring Programmes in Finnish Higher Education Mentors' Perspectives', Mentoring and Tutoring. Partnership in Learning, Vol. 22, No. 1, pp. 74-86.

Strong, M. (2011) The highly qualified teacher: What is teacher quality and how do we measure it? New York: Teachers College Press.

Štátny vzdelávaci program (2008-2009). ISCED 1, ISCED 2, ISCED, [Online], Available: http://www.statpedu.sk [Mar 2015]. Veteška, J., Tureckiová, M. (2008) Kompetence ve vzdělávaní. Praha: GradaPublishing.

Výbohová D. (2012) Príprava a realizácia adaptačného vzdelávania na škole, školskom zariadení, Bratislava: MPC.

Vyhláška MŠ SR No. 445/2009 o kontinuálnom vzdelávaní, kreditoch a atestáciách pedagogických zamestnancov a odborných zamestnancov. [Online], Available: https:// www.minedu.sk/vyhlaska-ministerstva-skolstva-slovenskejrepubliky-c-4452009-z-z-o-kontinualnom-vzdelavanikreditoch-a-atestaciach-pedagogickych-zamestnancov-aodbornych-zamestnancov/ [Mar 2015].

Zákon No. 317/2009 Z. z. o pedagogických zamestnancoch a odborných zamestnancoch. [Online], Available: https://www. minedu.sk/6826-sk/zakon-c-3172009-z-z-o-pedagogickychzamestnancoch-a-odbornych-zamestnancoch-a-o-zmene-adoplneni-niektorych-zakonov/

[Mar 2015].

Zumwalt, K., and Craig, E. (2005) 'Teachers' characteristics: Research on the indicators of quality', in Cochran-Smith, M. and Zeichner, K. M. (Eds.), Studying teacher education: The Report of the AERA Panel on Research and Teacher Education, Mahwah, N.J., pp. 157-260. 